\title{
The Legend of St. Brendan
}

\section{Author(s): Dominick Daly}

Source: The Celtic Review, Vol. 1, No. 2 (Oct., 1904), pp. 135-147

Stable URL: http://www.jstor.org/stable/30069787

\section{Accessed: 19-06-2016 09:55 UTC}

Your use of the JSTOR archive indicates your acceptance of the Terms \& Conditions of Use, available at

http://about.jstor.org/terms

JSTOR is a not-for-profit service that helps scholars, researchers, and students discover, use, and build upon a wide range of content in a trusted digital archive. We use information technology and tools to increase productivity and facilitate new forms of scholarship. For more information about JSTOR, please contact support@jstor.org. 
13. What son (mac) has not been brought forth, and will not be brought forth, and (yet) is named a son?

Easy (to say) : the mac alla, 'echo' (literally 'son of a cliff').

14. What are the animals that were not put into the ark and (yet) came out of it?

Easy (to say): Lucifer through envy breathed within, and made a mouse to kill them (Noah and his family) and to consume their food. Michael beheld him, and breathed into (. . . a cat ?) to kill the mouse. . . .

Here the MS. becomes illegible.

\section{THE LEGEND OF ST. BRENDAN}

\section{Dominick DaLY}

The pre-Columbian story, in varied forms, of a wonderful translantic land must be ranked as amongst the most ancient, widespread, and lasting of human legends. It was evidently old and familiar when Homer wrote the Odyssey, and if one might rely upon what Plato says about the Island of Atlantis and the ancient Egyptian priests, it pre-dated Grecian existence by many thousands of years. Its popularity endured through the pagan period, during the early and middle-age chronology, and even centuries afterwards.

The Celtic imagination of the peoples of the western shores of Europe was obviously greatly impressed by the romantic story, as is shown by the many early prose and poetic compositions which have survived to excite the interest of modern philosophers and antiquarians. Amongst those compositions are the Voyage of Bran, of the brothers Cora, of St. Brendan, of Mernoc, Maddoc, and others, which appeared in various Celtic languages and their translations.

Next to the Voyage of Bran (so learnedly and exhaustively treated upon in Mr. Alfred Nutt's two volumes) the so-called 'Legend of St. Brendan the Navigator' is perhaps the most 
interesting version, or expansion, of the ancient legend as it impressed itself on the Celtic mind. Throughout the whole of the Middle Ages it certainly seems to have been the best known and the most widely diffused of all popular stories. It existed in a multitude of forms, prose and metrical, and appeared in all the chief languages of Europe, and in some which are now wholly or nearly extinct, as--Romance, Flammand, Anglo-Norman, Low German, and Low Saxon, and in the older forms of Irish, Welsh, and Spanish.

It relates to the supposed marvellous adventures of a well-known and historic Irish saint in his voyage across the Atlantic about the middle of the sixth century. The original narrative, whatever may have been its character, must have undergone many modifications in the course of transcription and translation, because there are not only differences of detail in all the existing versions, but the earliest amongst them were written some centuries after the time of Brendan. Substantially, however, and in main outline and leading incidents, all the versions agree, and it may therefore be presumed that we have the legend pretty much in its original form.

The earliest versions do not date back further than the tenth or eleventh century, though it is thought that still older copies may exist in the MS. collections of European libraries. The Legend is referred to in the 'Roman du Renart,' one of the most ancient French poems :-

\footnotetext{
' Je fot savoir bon lai Breton, Et de Merlin et de Foucon, Del roi Artu et de Tristem, Del chievre oil de St. Brendan.'
}

Early MS. copies of the Legend exist in the Paris Bibliothèque, British Museum, Cottonian and Harlem collections, and in most of the European libraries. Camden and Ussher treat upon it, and more recently it has been reproduced or summarised by Coglan, Lanigan, Jubinal, Michel, Wright, von Schröder, and others. ${ }^{1}$ Coglan intended to make an exhaus-

1 Cottonian, Vespas., B. x, D.xi. Harlem MSS. 2277, folio 41. Camden, Brit.; Lond. 1722. Ussher, Antiq. Coglan, Acta Sancto. Lanigan, His. Ecc. Hib. Jubinal, 
tive search for all the versions which might be in existence, but died without accomplishing the task. In England the earliest translation appears to have been one in NormanFrench made by order of Adelaide of Louvain, queen of Henry I. The metrical version, which was long popular here, appears to have been published at the end of the thirteenth century, and it was probably from this source that Wynkyn de Wordes obtained the materials for the version which he published in 1520-27.

There seems no reason to doubt that St. Brendan was the author of the Legend attributed to him by general consensus. The saint was not only a scholar and a writer, but also an adventurous sailor who earned for himself the title of the 'Navigator,' which distinguishes him from another saint of the same name and period. Some of his compositions, which are said to be meritorious in their way, are extant and mentioned in Tanner's Biblió. Brit. Hib. ${ }^{1}$ In his duplicate character as a sailor and a saint he was very well qualified to write a book of marine adventures of a pious and edifying character. He was certainly familiar with Atlantic navigation, for (in addition to voyages to Wales and Scotland) he appears to have frequently sailed between Brittany and the west coast of Ireland. His early history is not material in this place, but he is thought to have been born about the year 484, and he died in 577 at the supposed age of ninety-four. His feast day is May 16 in the Roman Catholic calendar. He was a zealous monk and ardent missionary, always ready to travel by sea or land for the conversion of heathens and the salvation of souls. In Ireland he founded a religious order of 3000 monks who, under his 'rules,' supported themselves by cultivating the soil, tending cattle, and fishing. His headquarters were at Clonfert, on the extreme western shores of

La légende latine de S.B., aprè MSS. xi., xii., xiii. siècles ; Paris, 1836. Michel, Les voyages merveilleux de S.B., en vers des xii. siècle; Paris, 1878. Wright, S.B., a Mediaeval legend, etc., Percy Society, vol. 14 ; London, 1842. Schröder, Dr. Carl von, S.B., ein lateinischer und drei deutsche texte ; Erlangen, 1871.

1 Confessio Christiana. Charta colestis hereditatis. Monachorum Regula. Ligni vita. Revelations de futuris temporibus, otc. 
Kerry, where he built a monastery and church on the summit of a hill still known as St. Brendan's mountain. He had also founded a monastery in Brittany in atonement for the death by drowning of one whose life he thought he might have saved. It was at Clonfert that the idea is supposed to have occurred to him (when he must have been pretty well advanced in years) of making a protracted voyage into the western Atlantic with a view to testing the truth of the popular reports of inhabited countries far away in the west. $\mathrm{He}$ is said to have been particularly impressed on this point by his cousin Byrenthus, who told him of a godson of his named Mernoc who had actually reached a trans-Atlantic country of a new and strange description, and established a monastery there. How the news of this success reached Byrenthus is not stated. It is not positively asserted that Mernoc himself had returned; but Byrenthus 'had dreams,' and probably this was his only source of information about trans-Atlantic realms. Everything about Mernoc is vague, scanty, and confused, but probably an adventurous spirit like that of St. Brendan did not require any great stimulus to a marine enterprise such as that proposed to him by Byrenthus. Having well considered the matter, St. Brendan made a voyage to a lonely island off the west coast of Ireland, and there held consultation with a venerable hermit, St. Aude; and it was ultimately concluded between those two holy personages that Brendan had a 'call' which ought to be obeyed. ${ }^{1}$

Returning to his monastery in Kerry the saint at once set about preparing for his voyage. He caused a capacious hide boat to be built capable of accommodating a number of persons with provisions for a long voyage. The coracles or hide boats of the ancient Celts and other peoples were famous

1 A Low-German version of the Legend, of the fourteenth-fifteenth century, says St. Brendan on one occasion became so indignant at the extravagance of a book of miracles he was reading that he cast it into the fire. To correct his incredulity he received a divine command to traverse the seas for seven years in order to see for himself things quite as extraordinary as any recorded in the book he had so impiously destroyed. 
for their seagoing qualities. The better sort of them consisted of a frame of wickerwork or light wood covered with one or more thicknesses of ox or horse hide. The keel and gunwales were of wood. They were extremely buoyant, fairly lasting, and the smaller ones very portable. They were known to the Egyptians and other ancient peoples, as shown by their sculptures. Cæsar became acquainted with them in Britain, and used British made coracles in his Spanish campaigns. The larger sort carried a mast and sail, and often made lengthy sea voyages. Of this description the boat of St. Brendan is said to have been. The ribs, says the Legend, were of tough timber and covered with a kind of lattice work ('coulombes') which was protected on the outside by a covering of ox hide properly dressed, and having the seams carefully anointed with butter; within were two other coverings of skin similarly prepared. This triple-hided vessel was provisioned for forty days with everything necessary for human subsistence, and with a supply of butter to re-anoint the seams when necessary. ${ }^{1}$ Fourteen monks, including the saint himself, composed the original complement of the boat's crew, but at the last moment two more volunteers from the monastery were taken on board at their earnest request.

In the vessel so constructed and appointed the Saint and his confrères put off into the Atlantic, taking a southwesterly course. For fifteen days they sailed before a steady and favourable breeze, on the cessation of which they were carried along by ocean currents and fitful winds for another 15 days (some versions seem to say a month), arriving finally at a number of islands of so lovely a description, that the wanderers made no doubt they had reached 'the earthly

\footnotetext{
1 In the words of an eleventh century MS. at Paris, St. Brendan and those who were going with' him 'prisent ferremens et fisent une nachiele très légière costue et à coulombes de dehors, si com il est coustume en ces parties, et le couvrirent de cuirs de bues tanés en escorche de casine, et oinsent les jointures des piaus de bure, et misent ii autre apparillures d'autre cuir en le nef, et vivre de xl jours, et bure à apparillier les piaus que devoient couvrir le nef, et toutes autre choses pourfitables à usage de humainne.'
} 
paradise'-the veritable site of the Garden of Eden. The most beautiful fruits and flowers abounded, talking birds of brilliant and varied plumage flitted about amidst the luxuriant vegetation, and neither nocturnal darkness nor winter cold were known in those bright and happy lands. For seven years the enraptured mariners remained in those delightful regions, but not inactively. They made numerous voyages between and away from the islands which constituted their headquarters.

In one of those excursions towards the end of the seven years, after beating about the ocean for a long time, and experiencing storms and darkness, they arrived at what appeared to be a mainland, very fertile and full of trees. For many days (fifteen and forty are both given in different versions) they explored this country without coming to the end of it. At last they came to a mighty river which they were unable, and apparently unwilling, to cross-du reste, a supernatural personage conveniently presented himself, and admonished them against going further on that occasion. So they turned back, and having taken on board a quantity of fruit and specimens of the gems and precious stones lying about, they returned to their islands. This appears to have been their last excursion of any importance; and having refitted and provisioned their vessel, they set sail for home, and arrived at Clonfert at the end of three months, having been away from their monastery for 'seven successive Easters.'

Such is the Legend in general outline. The minute details, as already observed, vary greatly in order and character in the different versions, and there is a good deal of uncertainty where numbers are involved. The use of the Roman numerals seem to have led to errors in transcription; for instance, one version will give (say) xi. days, where another gives $x l$. days, the 1 being evidently mistaken for $i$, or vice versa. An air of probability is well maintained up to the stage where the islands are reached, after which the narrative at once becomes a veritable occidental Odyssey, of 
a monkish tone, full of preposterous but not wholly uninteresting incidents. There is, for example, a great fish which the saint and his companions mistake for an island, and upon the back of which they commence making a fire to cook their food before they discover their error. It is curious that the same incident should be given in Sindbad the Sailor. In common with some other similarities it suggests that the Legend must have found its way far eastward at a very early date, or that both incidents are derived from a common source (it might be Phœnician) of greater antiquity than either Sindbad or Brendan. ${ }^{1}$

The very first land reached by the voyagers, just as their provisions were running out, had the appearance of an enormous rock standing out of the sea. They were three days coasting along its shores before they found a landing place. After a stay of some days they continued their voyage westwards, and came to the 'Island of Sheep' and the 'Island of Birds.' In the former they found sheep as large as oxen, and in the latter birds who conversed with them in a highly religious strain, and who were, in fact, some of the fallen angels who had somewhat compromised themselves in the great rebellion of Satan, but not to a very serious extent. The monks also saw monstrous creatures of the sea and air-fish which threw out great quantities of water from their mouths, terrible griffins, etc. In one of their excursions they saw far away a hill on fire, emitting dense smoke and a horrible stench, and this was, of course, one of the mouths of hell. They also came upon Judas Iscariot sitting on a rock in the midst of the sea, enjoying a sort of temporary respite (an annual one, as he explained to them) from the torments of hell. Again, they are involved in a great storm which lasts many days, but are at length able to land on an island where they are handsomely entertained

1 Both Wright (Percy Society) and Schröder think that Sindbad's story is taken from the Brendan legend. The former observes that the early Arabian geographers appear to have been familiar with the Legend, because they refer to the 'Island of Sheep' and the 'Island of Birds' in the great western ocean beyond the Mediterranean, in the very language of the Legend. 
by a supernatural community of monks, gorgeously arrayed in copes of gold. In some parts they found the waters of the sea so clean that they could see the bottom at a great depth, and could observe the movements of the fishes, who (on St. Peter's day) came to the surface to hear Mass.

It is to be noted that St. Brendan is said to have made two voyages, the second in a wooden ship carrying sixty men. The second voyage was, however, frustrated by unfavourable weather, and nothing seems to have come of it.

Improbable as many of these incidents must have at all times appeared to reasonable minds, the Legend, nevertheless, was accepted for ages as true in substance, and as pointing to the veritable existence of a land beyond the Atlantic, which land St. Brendan had visited nearly a thousand years before Columbus. But indeed, as already observed, there is scarcely an older human tradition than that relating to a strange country, or number of islands, lying far away in the western ocean. From the earliest Babylonian times ${ }^{1}$ onwards through the classical and mediæval periods this belief was general and widespread. It was, no doubt, prevalent along the western shores and islands of Europe, long before St. Brendan. M. Gærres thinks that St. Brendan may have collected the materials for his Legend, in part at least, from Breton traditions. Humboldt mentions the prevalence of such traditions amongst the early Welsh, Irish, and Scandinavian nations. It is certain that the Spaniards and Portuguese long believed in the existence of St. Brendan's land. It is speculatively laid down on their older maps as west of the Canaries, or south of Antilia, and west of Cape Verd, and marked as 'San Borondon.' Even after the discovery of America (which might well have been accepted as a full satisfaction and settlement of the legend) 'St. Brendan's land,' as another and still undiscovered country, continued to find supporters. In the treaty of Evora, Portugal surrendered the Canaries to Spain, and also 'San Borondon,' should it be discovered. In the sixteenth and seventeenth centuries the

1 Smith's Chaldean Genesis. 
Spaniards made several attempts to find 'San Borondon,' and as late as 1721 Don Juan de Mur, Governor of the Canaries, fitted out a ship to search for it. The captain he commissioned, Gaspard Dominguez, sailed about for several months in the idle quest.

What amount of reality, if any, may underlie this curious and persistent Legend of St. Brendan's voyage is very diffcult to say. It may be all romance, as a great deal of it undoubtedly is, or there may be mixed up with it a tincture of reality. There is an initial probability that St. Brendan might have undertaken such a voyage, which would be quite consistent with his reputation; but it is equally probable that, as monk and a man of letters, he might have simply designed to write a religious and edifying romance, making use of his own marine knowledge and experience, and such hints as he might be able to gather from Breton and other traditions, to give a realistic colour to his work. Possibly his first voyage may have been little more satisfactory than his admittedly unsuccessful second voyage, and he may have consoled himself for his disappointments by writing an imaginative account of a voyage which was never completed.

In the Legend itself there is, undoubtedly, a good deal that is possible and even probable, and some things which, tested by our latter-day knowledge, seem curiously accurate. There is, of course, no improbability in a comparatively small vessel crossing the Atlantic. The feat has been performed before and since the introduction of steam by smaller and less seaworthy vessels than St. Brendan's hide-covered bark. It is remarkable that the favourable winds and ocean currents which carried the boat westwards are known phenomena, ${ }^{1}$ and the time which elapsed before land was reached is in accordance with modern experiences. It is not very likely that a mere romance writer of the sixth century would happen to be accurate upon points such as these if he were really ignorant about trade winds and ocean currents.

1 Captain Basil Hall on one occasion made the voyage between Land's End and Barbadoes in fifteen days' sail. 
The direction taken and the duration of the voyage might very well bring the saint and his companions to the West Indies, and it is another noteworthy circumstance that not only in geographical situation, but in climatic and other characteristics, the descriptions in the Legend are accurately applicable to the West Indies. Isolated coincidences are of small moment in considering the reliability of a doubtful account of a voyage of discovery, but numerous and relative coincidents are impressive. In the Legend (1) the distance traversed in a certain time, (2) the direction taken, (3) the winds and the currents, (4) the numerous peculiarities of the islands discovered, (5) their situation with respect to a continent beyond-all point clearly to the West Indies, and favour the presumption that the Legend is not purely a romance, but may have had a basis of actual knowledge and experience on the part of the writer or his informants. On some minor points in the narrative there is obvious exaggeration or distortion of very plain possibilities. The Sindbadian fish, and those which threw great quantities of water from their mouths, are easily reducible to spouting whales; and the conversational birds may very safely be taken to be parrots, with whose powers of 'talking,' or imitating human speech, the saint and his companions seem to have had ample opportunity of becoming acquainted. The 'sheep as large as oxen' may possibly have some relation to animals of the Guanaco or Paco species, which Darwin says ${ }^{1}$ were once much more widely distributed than at present, and which the Spaniards, who first beheld them in South America, described as 'large sheep.' What are spoken of in the Legend as 'ruins of castles,' on the main land, may be as unreal as Judas sitting on the rock, but we of to-day know that if St. Brendan had gone far enough westward he might have seen in abundance ruins of ancient cities and mounds which were probably then more numerous and conspicuous than at present.

In the Gentleman's Magazine of August 1888, in an article on the indications of early Christian teaching in Mexico,

\footnotetext{
1 Voyage of the 'Beagle.'
} 
it was diffidently suggested by the present writer that St. Brendan might have been the early teacher whom the Mexicans knew as Quetzatcoatl, and whom they said was a bearded white man who had come from the west in a sailing-boat.

' In respect to epoch, personal characteristics, race, religion, direction of coming and going, the Mexican Messiah might well have been the Irish saint. Both were white men, both well advanced in years, both crossed the Atlantic from the direction of Europe, both preached Christian doctrines and Christian practices, both returned across the Atlantic to an insular home on Holy Island, both intended to come back, but failed in doing so. The date of St. Brendan's royage-the middle of the sixth century-is conveniently within the limits which probability would assign to the period of Quetzatcoatl's sojourn in Mexico, namely, from about the fifth to the eighth centuries. The possibility of making a voyage in such an age from the western shores of Europe to Mexico is proved by the fact that the voyage was made by Quetzatcoatl, whatever part of Europe he may have belonged to. The probability of St. Brendan designing such a voyage is supported alike by the renown of the saint as a "navigator" and by the known maritime enterprise and enthusiastic missionary spirit of the Irish of his time; the supposition that he succeeded in his design is countenanced by the ample preparations he is said to have made for the voyage. ... It would be presumptuous to claim that the identity of Quetzatcoatl with St. Brendan has been completely established in this essay, but it may reasonably be submitted that there is no violent inconsistency involved in the theory herein advanced, and an examination of the evidence upon which it is based discloses many remarkable coincidences in favour of the opinion that the Mexican Messiah may have been the Irish saint.'

However interesting and plausible this theory may be, it must be admitted that it is but slenderly sustained by the Legend when carefully considered, and is somewhat strongly rebutted by what the Legend does not say. According to all versions the saint's stay on the mainland (even supposing it be Mexico) was of very brief duration-only a matter of days -and he claims to have done no missionary work during the time. The Mexican tradition gives twenty years as the duration of Quetzatcoatl's mission, and certainly the work he

voL. I. 
did was of such a solid and lasting character as to have required a period of at least some years under the most favourable circumstances. Nor does the Legend claim any credit of the kind for St. Brendan-a significant omission. If he had accomplished any missionary work during his seven years' absence, a record of the fact would surely have been found in the Legend. The assumption, therefore, of his being Quetzatcoatl is not well borne out, and the honour of that identity must be reserved for some other European-possibly of about the same period-possibly Mernoc. The omission from the Legend of all mention of missionary work has a still wider import, and tends to throw doubt upon the Legend as a whole. There is no mention made in it of native populations or of women or children, and it is not to be supposed that the countries described were uninhabited except by those incredible communities of monks and supernatural personages described in the Legend. Where so much that is trivial has been preserved and magnified-where so much unreality has been invented-it is remarkable that not a word should be found in the Legend touching aborigines or efforts at their conversion.

Probably the inferences which, on the whole, are most likely to be correct are the following:-1. The Legend is partly true, or founded on fact. 2. St. Brendan made some attempt to cross the Atlantic, but did not succeed. 3. He wrote in part from his own marine experiences, but he had, from some source or another, correct hints in relation to the West Indies and the continent lying beyond. The particulars in the Legend touching the West Indies seem too numerous and precise to be quite accidental; yet if St. Brendan had himself collected those particulars in actual experience, he would almost certainly have told more than appears in the Legend. No question of a lost chapter, or of intentional repression of a part of the story, arises. The Legend is complete in itself and free from any suspicion of a hiatus; andfar from there being any reason to suspect omission of parts relating to pagan peoples-it is certain that anything of the 
kind would have been carefully preserved, and probably highly magnified, either by the saint or his biographers. The actual life of St. Brendan is singularly well known, considering the remoteness of his period, and nowhere in his biography is there a hint of his having made converts in his voyage across the Atlantic. So that in spite of the many probabilities presented by the Legend, the most that can be said is that Brendan seems to have had some correct information about the direction, distance, situation, and natural characteristics of the West Indian Islands and the continent beyond, but such information was mere hearsay, and very vague and scanty.

\title{
A JACOBITE WAULKING SONG
}

\section{E. C. Carmichael}

THIs song is known, in versions more or less imperfect, in the Hebrides. I took down this and other forms in Barra, my father has taken down versions which differ in several details, and I know other collectors who have yet other variations. All reciters, however, agree that 'Mac mo righ' is Prince Charlie. 'Mac 'ic Dhughail' is the patronymic of Macdonald of Morar. I have retained 'localisms' which seem in keeping with folk-songs. The chorus follows each line, as printed at the beginning -a characteristic of waulking songs.

\section{AN FHIDEAG AIRGID}

\author{
Hi ri liuthil o, \\ Co a sheinneas an fhideag airgid? \\ Hō rŏ huó hiuthil ó, \\ Mac mo righ-s' air tigh'nn a dh' Alba \\ Hi ri liuthil $\delta$, \\ Air luing mhoir thar na fairgeadh, \\ Hō rơ huó hiuthil ó, \\ 'S air luing riomhaich nam ball airgid, \\ Le stiuir oir is da chrann airgid, \\ 'S cupuill oirr' de shiod na Gailbhein, \\ 'S ulagan oir air gach ceann di.
}

